\title{
CHRISTMAS SONGS AND CONSTRUCTING IDENTITIES
}

\section{MARIJA KLOBČAR}

Izhodiščno vprašanje - "Ali obstaja evropska dedišcina pesmi ali europska dedišcina v pesmib" - ni le vprašanje Evrope, dedišcine in pesmi: vodi $k$ globljemu razmisleku o identiteti, ki presega nacionalne okvire. Ob opazovanju tega problema ne moremo mimo iskanja nacionalne identitete, ideoloških razločkov, sočasnih političnih pritiskov in globalizacije. Ali lahko Evropo - upoštevajoč vse te značilnosti - razumemo kot posebni kulturni prostor, ki se izraža tudi v pesmih ali z njimi, ali je to le nova umišljena skupnost? - Slovenski etnični prostor zaradi posebnih zgodovinskih in prostorskih stičičč za tak premislek ponuja izredne možnosti. S pozornostjo do božičnih pesmi tako skuśa prispevek ugotoviti, kaj vse je vplivalo na podobo slovenskega doživljanja božiča v preteklosti, kako je na pesmi in na doživljanje božiča vplival socializem, ki je praznovanje božiča potisnil v zasebnost, in kakšne spremembe sta prinesli slovenska osamosvojitev in tranzicija, ko sta tržiščce in medijski prostor vstopila v zasebni svet Slovencev, božič pa je postal del javnega življenja. Z opazovanjem teh procesov prispevek odpira tudi vprašanja o razmerju med pesemsko dedišcino in koncepti identifikacije.

Ključne besede: božične pesmi, identiteta, obredje, dedišcina.
The basic question addressed in this paper - "Is there a European song heritage or a European heritage in songs?" - is not just a question of Europe, heritage and songs: it leads to the deeper issue of identity that extends beyond national frameworks. The study of these issues cannot ignore the struggle for national identity, ideological differences, contemporary political tensions, and globalization. Taking all of these into consideration, can Europe be understood as a special cultural space with its expression in or using songs, or is it just a new imagined community? - For this kind of study, Slovenian ethnic territory offers remarkable opportunities due to its exceptional historical and spatial meeting points. By concentrating on Christmas songs this paper seeks to determine what the past influences were upon the image of the Slovenian Christmas experience. This study also examines how communism, which relegated the celebration of Christmas to the private sphere, influenced these songs and the Christmas experience, as well as the kinds of changes engendered by Slovenian independence and transition, when the market and the media entered Slovenians' home lives and Christmas became part of the public sphere. This paper considers these processes in order to address the question of the relationship between song heritage and concepts of identification.

Keywords: Christmas songs, identity, rituals, heritage.

\section{TRANSITION: BACK TO SLOVENIAN, EUROPEAN, GLOBAL?}

In December 1989, when Slovenia was gradually attempting to shake off the mental rigidity of communism with its announcement of a multiparty political system, the first public postwar display of nativity scenes took place at the Kmečki glas (Farming News) office in Ljubljana. It was accompanied by Christmas music recorded on a cassette. The media began publishing greeting cards that included the previously forbidden symbols of Christmas, although they very cautiously opened the door to this different view: We wish everyone a happy and successful 1990, and Merry Christmas to those that will celebrate it (Kamniški ... 
1989). The public celebration of Christmas was a harbinger of the political changes in Yugoslavia that would lead to a new political map of Europe over the following decade.

Only one year later, another important sign of social change in the Christmas holiday was marked by the return of carolers, who went from door to door between Christmas and Epiphany. For some Slovenians, the revival of Three Kings caroling after fifty years was a return to older, typical Slovenian customs; a return to the time before communism. Others understood it as a return to publicly identifying Slovenian culture as Christian, or as a public opening toward the West; some saw it merely as a return of the private to the public sphere. At that time the phenomenon was more visible than the songs themselves. The needs of caroling groups were also met by a collection of carols that attempted to span the forty-year interruption of the tradition (Kumer 1995).

The restoration of Christmas was not just a simple return after four decades of silence. Even before Christmas could be mentioned in public, the figure of Santa Claus appeared on New Year greetings (Kamniški ... 1988), which - along with songs characteristic of American Christmas celebrations - over time was incorporated into and sometimes even overwhelmed the Slovenian Christmas celebration. Children brought these songs home from school and they quickly became component parts of not only public celebrations (Jarc 2009), but also private ones. Christmas thus returned in a form different from the one that had been withdrawn for political reasons decades earlier. At the same time, the search for Slovenian identity was also evident in songs.

The new public celebration of Christmas therefore uncovered the exceptional differentiation of contemporary Slovenian society, or very diverse forms of self-identification. The various influences opened the question of inventing tradition (Hobsbawm 1983) and seeking its reflection in songs. Songs were a way of signaling experiences and changes, but at the same time they created the impression of the holiday's continuity. The issue of this relationship - the stability of certain figures and responses, and the addition of new ones, as well as the issue of the borders that these demarcate - means these songs deserve special consideration. They signify the borders that delineate or erase the borders of Slovenian and European identity.

\section{THE HIDDEN IMAGE OF CHRISTMAS BEYOND IDENTITY}

The traces of identity that extended beyond national borders in the past are preserved much more in rituals than in songs. The pre-Christian beliefs tied to the winter solstice expressed in songs are preserved only among the Slovenians in Austrian Carinthia, who did not experience the ideological break after World War II. ${ }^{1}$ In their caroling, which shifted to before Epiphany, they preserved the demonic figure of Perchta (Sln. Pehtra, Pierhta, etc.),

1 This custom has been preserved around Zahomec/Achomitz, Drevlje/Dreulach, and Gorje/Göriach (Milisavljevič 1999: 9). 
which accompanied carolers' singing. They thereby preserved an unconscious continuity that reflected the traces of old beliefs, but not affiliation with a particular community. The figure of Perchta, which is characteristic of beliefs in the broader Alpine region (see Blaumeiser \& Blimlinger 1993: 284), therefore preserved one of the figures from the old Indo-European tradition in songs with an entirely different ideological background. Perchta is therefore an interesting example of the connection between ancient Indo-Europeans masquerading as demons and Christmas caroling, but the appearance of this figure does not indicate identification with a certain community.

The pre-Christian relationship with the dead had already faded almost completely from the Christmas rounds. Aside from Perchta, in Slovenia the only other ancient tradition that was preserved was the otepovci, or "thrashers," who went caroling before New Year in the Upper Bohinj Valley. The song that accompanied this tradition has not been preserved. The pre-Christian heritage remained much more evident in Christmas customs that were no longer connected with songs, such as lighting the Yule log, telling fortunes by dripping molten lead in water, blessing the houses, stables, and fields, and the special bread made for visitors from the afterworld. In songs, the memory of the magical powers of this holy night was preserved only in old transcriptions relating to Christmas Eve: So vse gore zvate ble, I so vse vode $z$ vinam takle (All the mountains were gold, / all the waters ran with wine) (SNP 3: 24, no. 4770).

As a result of opposition from the Church, magical pre-Christian elements had already moved into the private sphere centuries ago. At the same time, despite its breadth, IndoEuropean heritage was not a conscious expression of belonging to a wider community, but rather a spontaneous response to the powers and phenomena of nature; an expression of the archetypical in man. The Christmas caroling rounds - a continuation of the previous visits of departed ancestors - had been completely Christianized and had changed their content and meaning. They had been imbued and enriched with elements from the medieval Christmas liturgy (Kuret 1970: 147). This process reflected the relationship to the community that had formed along with Christianization. In European lands, this resulted in conscious recognition of shared features and solidified the awareness of belonging, but at the same time preserved old distinctions.

\section{CHRISTMAS CAROLS: A REFLECTION OF CONNECTIONS AND DIVISIONS IN EUROPE}

Christmas clearly expressed Christian tradition and the awareness of belonging to the community this tradition represented. This community was differentiated and expressed many and varied traces of earlier social processes. These traces can be found not only in song lyrics, but also in their contexts, which indicate the polarization within Christianity.

The first polarization, which had split the Church into its eastern and western parts, and 
also left traces in various additional celebrations of Christmas, was preserved in Slovenian folk song in the form of the celebration of the Orthodox Uskoks in Bela krajina (White Carniola). The opinion that White Carniola caroling contains stereotypical verses from Croatian caroling (Milčetić 1917: 74) and the mention of these common features nevertheless raises the question of whether this has to do with a shared pre-Christian heritage or is the mark of later contact; that is, caroling.

The tradition that was shaped in Slovenian ethnic territory as a consequence of the ideological split during the Reformation - the era of ideological polarization between Catholicism and Protestantism - had broader repercussions. In 1575 the Slovenian Protestant reformer Primož Trubar reported on Christmas caroling in his Katekizm z dvema izlagama (Catechism with Two Commentaries) (Oblak 1891: 141); this report is also the oldest attestation of folk songs in Slovenia. In Trubar's Catechism this is not merely a neutral report on folk songs, however, but rather a negative attitude toward piety that departs from authentic teaching. That is, he opposed caroling, which took place under the auspices of the Catholic Church and served its interests (Trubar 1575: 217-218).

Religious splits caused differentiation in the adoption of songs that spread to the people from the liturgy: the Central European area where these songs were sung underwent differentiation during the Reformation process. This division is evident in the song Eno dete je rojeno (A Child is Born), whose source is the Latin song Puer natus in Bethlehem (A Child is Born in Bethlehem). In Slovenia, the song was used by both Protestants and Catholics, but its role for each was different. It was first published in 1563 in the Protestant songbook Ene duhovne peisni (Some Sacred Songs), but after the decline of the Reformation it only appeared in its Catholic version. This was preserved in both print and oral tradition (Kumer 1958: 3): among Catholics it was known as a sacred folk song and a carol (Kumer 1958: 68).

The Latin carol Puer natus in Bethlehem therefore demonstrates religious differentiation in Slovenian ethnic territory, but at the same time it shows this area's connection with the outside: numerous translations and arrangements of the song are found throughout all of Europe. Among the South Slavs, the Croatians also knew it; other groups included the Sorbs, Germans, Danes, Norwegians, Lithuanians, Romansch, and probably also other European ethnic groups (Kumer 1958: 42-43). This connection based on religious affiliation was stronger than linguistic borders.

The polarization between Catholicism and Protestantism that split Europe in the $16^{\text {th }}$ century also shaped perspectives on older tradition. It was this process that shaped the images of invented tradition expressed by songs during the $17^{\text {th }}$ century (Hobsbawm 2002: 7). While the Catholics tried to reshape the older tradition by adding new elements, the Protestants tried to replace that tradition with earnest sung messages about the essence of Christmas. Trubar's objection must then be compared with the broader Protestant stance, such as that represented in England by Oliver Cromwell (Bowden 1980), which successfully eliminated traces of the older song tradition (Lloyd 1967: 134). Therefore, in this duality 
it was already possible to sense the differentiation but also the unity of European culture. The Slovenian-speaking areas experienced this polarization to a great degree. ${ }^{2}$

At this time, under the influence of the Reformation and humanism in Central Europe, the custom of Epiphany caroling began (cf. Kuret 1970: 296), which was a socially recognized form of ritual rounds with singing and was associated with the Christmas season in Central European lands. In the $17^{\text {th }}$ century, the polymath J. W. Valvasor described caroling for church candles, which took place in Slovenia between the feast of St. Nicholas and Candlemas. He noted parallels between this and the German carolers known as Sternsinger (Rupel 1969: 275). The bearers of this invented tradition were prominent members of the community. This caroling was carried out to meet church needs, and it died out within two centuries (Turnšek 1943: 51).

Acceptance of this new form of caroling is another indication that the Slovenian lands were a part of Central Europe. From this point of view, their affiliation with the Central European cultural area was continually confirmed over the following centuries, particularly through the influence of their German-speaking neighbors. It was already evident at the end of the $19^{\text {th }}$ century - which saw the publication of the first scholarly collection of Slovenian folk songs - that songs had also come to Slovenia from German-speaking areas. The editor of the collection, Karel Štrekelj, became aware of this German tradition only when the songs were already included in the collection. In keeping with the orientation of folklore studies as a discipline that was to build a national identity, he perceived this as a lapse: Likewise, the song 'Enu je dete rojenu, Notri u mestu Betlehem' was improperly included among the national Christmas carols . . because it is simply a free translation of an old Latin, or German, Christmas carol (SNP 3: IV).

At the end of the $19^{\text {th }}$ century, traces of the caroling drawn from Christmas plays - the pastoral or shepherds' caroling - were still very much alive in the song tradition. These were Christmas songs in dialogue (Kuret 1986: 7). Their transmission across linguistic borders is attested, however. Štrekelj was also aware of their foreign origin, but despite this he did not entirely reject it:

Some other Christmas songs, mostly pastorals, will be included. They came to us from German but not so much through Church influence - their tone is definitely not sacred - but through Christmas plays, which used

2 Today the expression 'caroling' can be misleading if these differences are not taken into account: it can have different semantic backgrounds in different cultural surroundings. Caroling is thus a broader concept in Slovenia than it is in English-speaking cultures. Folk forms of ritual rounds with singing (i.e., caroling) have been preserved in Slovenia for various holidays; in addition to caroling between Christmas and Epiphany, the other most significant holiday is the time around Midsummer. For Slovenians, then, Christmas caroling was only one of a series of ritual rounds with singing, with which their predecessors responded to natural events. In addition, there was never any caroling on Christmas Eve in Slovenia. The expression caroling may therefore be somewhat misleading because in modern, popular English usage this has semantically narrowed to primarily denote singing on Christmas Eve like that practiced in England (Russell 2006), in which the bearers of the tradition were prominent members of the community. 
to be (and apparently still are today) presented mostly among Carinthian Slovenians; this is indicated by the jocular, and occasionally pointed, goodhumored answers from the performers, which have been preserved in these songs. (SNP 3: IV-V)

In some cases even the memory of where the song came from is preserved; this information is sometimes very personal and unreliable. With the song "Le čuj, le čuj, ljub sosed moj" (Just Hark, Just Hark, Dear Neighbor of Mine), which was fairly widespread in the Littoral, a memory was preserved in the village Lokovec of a Friulian that was believed to have brought the song to the village. The song was also known in some places in central Slovenia, such as Kropa, a Carniolan town with a metalworking tradition. This does not exclude the possibility that the transmission path of this song was the trade route between Slovenian metalworking areas and Friuli. The carol was published in the newsletter Zadrugar (Stare 1940) along with songs that had appeared before 1830 but had already been forgotten.

Furthermore, in Slovenian ethnic territory, a more ancient caroling tradition that was not connected with church also survived. It was only one of several ritual rounds with singing, which were usually (and are still in part) carried out for many holidays in the winter, but also in the spring and summer months. 'Secular caroling' at Christmas was subject to the same process of transformation as other ritual rounds connected with pre-Christian traditions. The most significant expression of these changes was the emergence of a jocular tone in the songs and caroling itself, which completely relativized the power of the ancient pre-Christian beliefs. As Štrekelj reported: One man told me that in their day they had sung much 'funnier songs' and that the carolers had acted crazier. I wrote down a bit of one of these silly wishes from the old days and this is how it went:

Bog vam daj toliko dobrote,

ko je na peci mokrote;

Bog vam daj toliko sreče,

ko je na peči zelene leče!

Bog vam daj toliko otrok,

ko je ajdovskih kop;

da bi imele kobile pišceta,

krave žrebeta in kvokle teleta!'
May God give you as much food

As your stove is wet;

May God give you as much joy

As there are green lentils on your stove;

May God give you as many children

As there are sheaves of buckwheat;

So that mares will have chickens,

Cows foals, and hens calves!

(SNP 3:7)

This frivolity, which is a sign that a custom is dying out, also contains a hidden message about ancient folk caroling: magical wishes for good luck. Up to the end of the $19^{\text {th }}$ century, when the Slovenian folk-song collection was prepared, less was known about this caroling; today these songs are mostly forgotten.

In the $19^{\text {th }}$ century, Christmas caroling gradually merged with New Year caroling; upon publication of the carols at the beginning of the $20^{\text {th }}$ century, the editor Karel Štrekelj wrote that today there are no longer true carolers and caroling. Now it is just musicians walking 
around (SNP 3: 6-7). Participation in these musicians' rounds, and rounds by other relatively permanent groups that passed between ethnic groups, is demonstrated by the song tradition itself. This also indicates a tradition that arose in the $19^{\text {th }}$ century in a completely different social context, among urban dwellers. The holiday itself in the broad European context then underwent a significant transformation.

\section{CHRISTMAS MOVES INTO THE PRIVATE SPHERE: THE URBAN FORM OF THE HOLIDAY}

At the beginning of the $19^{\text {th }}$ century, German ethnic territory, whose traditions heavily influenced the Slovenian population nearby, experienced significant social changes: accompanying these was a shift of Christmas to the private sphere. Christmas, as a special social season, is therefore an expression of a broader social process: Christmas celebrations themselves most visibly reflected urban culture. As an expression of their economic and social status, city dwellers shaped different celebrations, which were removed to their private worlds. The background of this shift is believed to have been the separation of the workplace and the home (Blaumeiser and Blimlinger 1993: 290).

This was also the time when the interests of urban society triggered national self-identification and sought recognizable symbols for it. One of the most contradictory urban Christmas symbols, which was also very widespread in Slovenia, was the Christmas tree. Slovenians were partly familiar with its history: up to the early $19^{\text {th }}$ century, the Christmas tree was a custom of aristocratic and prominent burgher families in Germany. During the Franco-Prussian war, soldiers erected a Christmas tree at the front in 1870, as a nationally recognized symbol of encouragement. This signified the spread of this phenomenon to other classes (Blaumeiser and Blimlinger 1993: 292), and soon also beyond national borders. In Slovenia this new tradition remained in its original social frame: Slovenian townspeople knew it, along with the custom of giving Christmas gifts, by the end of the $19^{\text {th }}$ century. Up to the Second World War the custom was largely preserved only among urban dwellers.

The $19^{\text {th }}$ century was also marked by the adoption of the song "Silent Night," and was also a time of distinct national self-definition, along with resistance to foreign influences that threatened this nationality. Whereas the Christmas tree came to Slovenia toward the end of the $19^{\text {th }}$ century as a 'German item' (and some nationally conscious townspeople therefore did not adopt it), the song "Silent Night" spread without national prejudices. At the same time that folk songs were being collected as an indication of national affiliation, the Christmas season in Slovenia was becoming ever more symbolically marked by this song.

The custom of Christmas tree thus had a specifically German cultural impact, whereas the song "Silent Night" became not just European, but international. In 1918, the presumed $100^{\text {th }}$ anniversary of the composition of this song, an article was published in the magazine Slovenska družina (The Slovenian Family) titled "The Origin of the Christmas 


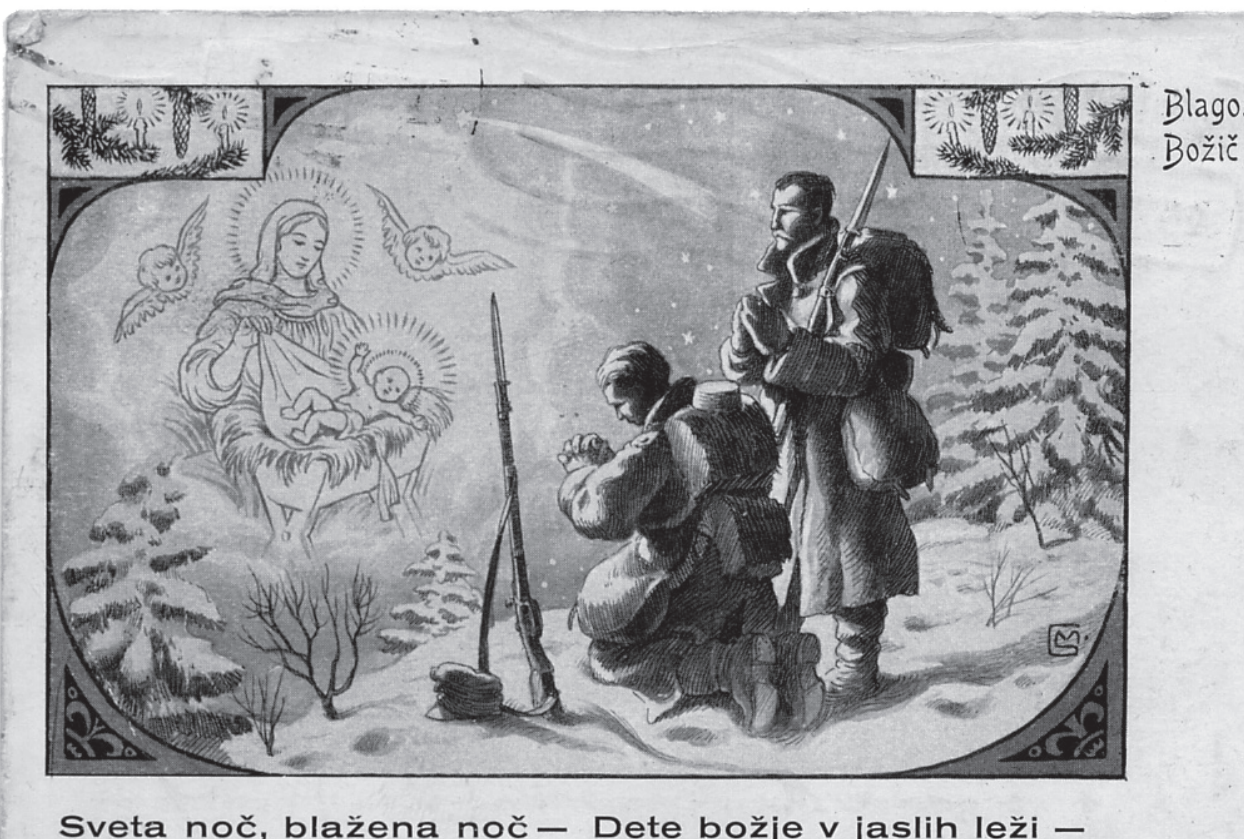

The acceptance of songs may conceal not only social differences, but also opposition between nations: the song "Silent Night" reminded soldiers of home on both sides of the front. - A war postcard by Maksim Gaspari from the cycle War in Pictures, printed during World War I. [Map and picture collection of the Ljubljana National and University Library].

Song 'Silent Night, Holy Night'.' The author marked the anniversary with a description of the circumstances surrounding the composition of the song and indicated the role the song had in Slovenia at the conclusion of the First World War:

on that holy night, when thousands and thousands of candles on Christmas trees and humble nativity scenes sparkle in the eyes of happy children, then the sounds of that sweet song ring out from countless churches and illuminated houses: 'Silent Night, Holy Night'. (Jagodic 1918-1919: 187)

He also pointed to the significance of the song among nations:

"Silent Night, Holy Night" has become an international folk song. It has taken over not only the German-speaking lands, the south and the north, but it has also broken through to the east and the west, and it has been adopted with enthusiasm and openness everywhere. We Slovenians know it well, and the Croats and Serbs have been singing it for over eighty years already. . . . Today it is sung by Moorish Christians (blacks) in Africa, as well as Indians in America. Missionaries have spread the song all the way to far-off China and the high mountains to the north. (Jagodic 1918-1919: 187-188)

"Silent Night," which was used as a greeting on Slovenian military postcards by Slovenian men during the First World War as a way of expressing Slovenian domesticity, 
was called an 'international folk song' by the end of the war. The song indicated a collective identity that in fact did not exist.

\section{FROM THE DENIAL OF CHRISTMAS TO NEW MYTHOLOGIES AND NEW CULTURAL AFFILIATIONS}

During World War II the Yugoslav partisan leader Josip Broz Tito used to wish his combatants a Merry Christmas. As a part of Yugoslavia's dechristianization in the early 1950s (Rihtman-Auguštin 1999: 48), Christmas was driven out of the public sphere in Slovenia, then a republic of the Socialist Federal Republic of Yugoslavia. The mythological space that had thus far been occupied by the Christian tradition was filled by the figure of Father Frost from the end of 1949 (Ciciban 1949/50: 56), replacing the traditional mythological benefactor, St. Nicholas (Sln. Miklavž). Father Frost expressly emphasized an orientation toward the East and the Soviet Union: it symbolically shaped and emphasized affiliation with another community, just as the experience of Christmas had up until then.

From 1950 onwards, Christmas Day was a workday. The Christmas tree, which up until the Second World War had been a sign of German identity to some and an expression of urban culture to others, was ideologically unfit. It was renamed the 'New Year fir', and in the early fifties it could not be displayed in public until the day after Christmas, 26 December. The days preceding the holidays and the holidays themselves were deliberately filled with other celebrations or activities, while the New Year celebration was given significantly greater weight, accented by the new mythological figure, Father Frost: in other words, the political orientation toward the East had to be supported with new celebrations, which also required a new mythological background. It was a strong sign of identity switching (Elwert 2002: 35), which was much stronger on the public level than on the private one.

The new ideology not only brought a new mythology, but also new song creativity. During the forty-year ban on public Christmas celebrations, two generations grew up singing songs about the new mythological figure, Father Frost: these songs therefore became part of tradition. Christmas and Christmas songs remained in the private sphere, either as part of a religious holiday or simply tradition.

Over time the opposition to Christmas weakened, just as economic cooperation blunted the political animosity toward Western culture. The official return of Christmas toward the end of the 1980s coincided with efforts to form an independent Slovenian state. Celebrating Christmas was meant to signify falling back on tradition, primarily in its folk form, which had had a very significant role during the 19th-century process of Slovenian national self-identification. On the surface, this was most visible in the revival of Epiphany caroling, which also had different goals than it had in decades past: it was equated with the missionary caroling that had begun after World War II in neighboring countries, and had included cross-border Slovenians (Kolar 2002: 325-326). 
While Christmas was being restored to the form of a widely understood tradition, the media and retailers also brought a form of the holiday into Slovenia that until then had mostly been known from TV. This was visible primarily in the new mythological figure, Santa Claus, in gift-giving, and in Christmas songs that were generally perceived as American Christmas songs. This act of replacing the replacement (Rihtman-Auguštin 1999: 51) had a strong impact on the young generation. "Jingle Bells," the widespread American Christmas song originally written for Thanksgiving (Jingle ... 2004), was routinely played in public settings, even in Slovenian translation (Cin ... 2007). On the surface, Christmas was defined as a family holiday: this definition was also used by the communist elite to excuse its revival. In actuality, it returned to the public sphere as a commercial holiday, which fit the contemporary consumerist orientation and opening to Western markets. The beginning of the holiday season is marked by holiday specials in the stores, which begin as early as November.

In addition to nativity scenes, song heritage also had an exceptional role in the restoration of Christmas, but not the same role that it had when Christmas was removed to the private sphere following World War Two. In some aspects the search for a 'Slovenian Christmas' was evident, but this unavoidably included traces of general European tradition: the composition "Slovenian Christmas,"3 for instance, which marked the return of Christmas and Slovenia's independence, includes the song "Eno je Dete rojeno" (A Child is Born) (Smolik 1993: 35). This old Latin song, found in many European countries, was testimony to an identity that extended beyond national frames despite aspiring to be national.

However, the song forms that had been preserved in church remained in people's consciousness and the private sphere. In this, the song "Silent Night" was perceived to be wholly Slovenian. Despite its multifaceted significance, it also signified a Christmas symbol that had spanned regional and social differences in Slovenian celebrations. Folklore studies perceived the song differently: it was not recorded as a folk song; nor was it included in folk song publications, even though the production principle for defining folk song material had already been surpassed at the beginning of the 20 $0^{\text {th }}$ century (Glonar 1923).

During a period when Europe was marked by extensive political changes, Christmas brought both a return of tradition and a 'breath of the West' simultaneously. Songs in this context act as conceptual celebration patterns; as an expression of continuity and change or tradition and innovation. Here, continuity refers not only to the domestic song heritage, but also the Central European heritage that fits Slovenians' traditional experience of Christmas. This is largely songs from German-speaking areas, including the song "Silent Night." In addition, English-language songs such as "Jingle Bells" are also continually gaining ground, as a reflection of the contemporary American experience. They come into the home largely through their transmission at schools, where their playful tone makes them popular with

It was based on a collection from central Slovenia (Kramar 1933). 
The Slovenian Christmas representations from the mid-20th century onwards reflect the issue of identity switching. The visual and sound symbols of the traditional Slovenian Christmas, which Father Frost was supposed to replace after World War II, began to feature the American figure of Santa Claus after Slovenia became independent. [Ad by the German retailer Takko from 2007; St. Nicholas resembles Santa Claus].

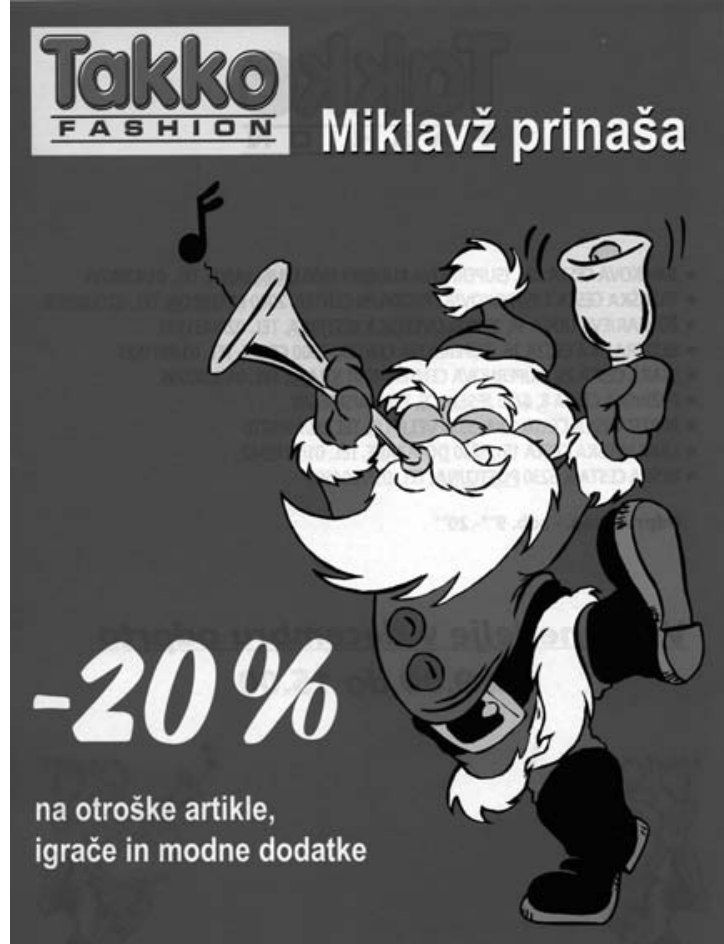

Akcija traja od 28.11. do 01.12.2007

children, and with the new consumerist mentality, which is also a basis of Eurocentrism (cf. Brumen 1997: 136).

The Slovenian form of Christmas nearly two decades after its restoration therefore reflects broad social processes and also various times and places. Both relationships with culture - the search for heritage and the new - are interwoven, and the traditional mythological benefactor, St. Nicholas, who is known throughout the entire Alpine region, has also taken on a different form due to contamination by Santa Claus. The 'West' was the 'Promised Land' to Slovenians for too long for them to be able to see its negative side when the borders finally opened up.

\section{IS THERE A EUROPEAN HERITAGE OF/IN SONGS OR SOMEWHERE ELSE?}

This overview of the influences that have shaped and are still shaping the song forms of Christmas celebrations in Slovenia, despite their surface continuity and faithfulness to tradition, demonstrates its integration into broader social events. It delineates divisions that had and still have influence on the sense of affiliation with particular communities. Songs are a way of signaling changes, and at the same time they themselves shape the holiday. 
Considering the influences that have shaped Christmas in Slovenia, it is possible to detect several historical times and places in today's form. It represents unconscious heritage of the pre-Christian beliefs tied to the winter solstice; the conscious affiliation with European culture that came with the adoption of Christianity; communism, which interrupted this process in public and drew attention to the political affiliation of Slovenia with the East; and the revival of Christmas as a public holiday.

Celebrations have symbolic power; Christmas ones especially, and so there remains the question of the extent to which elements of shared song heritage indicate actual ties. Christmas song content, because of its ideological message and psychological effect, appears to bring people closer together, but this is actually more an equivalent response than an actual closeness. Songs can indicate greater closeness among ethnic groups than there actually was. This context illuminates the statement that folklore is not simply a way of obtaining available data about identity for social scientists, and that it is actually one of the principal means by which an individual and a group discovers or establishes his or its identity (Dundes 1996: 35).

At the same time one cannot avoid social responsibility, even in folklore research: although Christmas songs for instance indicate greater closeness than there actually was, they do indicate certain identities. This overview of Slovenian Christmas songs has shown the variety of influences that had their impact on identity, and it is difficult to deny that nearly everybody is placed in a multidimensional space of identity criteria (Haneke 2002: 150). The resistance to American-style Christmas experienced in France in the early 1950s (Rihtman-Auguštin 1999: 50) or today in Germany (Rettet ... 2005) offers a sign of an identity that wants to distinguish itself from the American one: identity requires the articulation of otherness (Kaiser 2002: 183). Although the globalization of culture is not the same as its homogenization (Muršič 1999: 145), this seems to be precisely the answer to globalization.

Is it therefore possible to study song transmission without context, or can one address the question of shared European song heritage without simultaneously asking about the things that connect it with life? The answer is provided by the time we live in, when globalization is broadening the perspective on a wider community,

We adopt songs if the actual presence of those they come from does not hinder us. At the global level, Europe is experiencing this and making efforts to demonstrate ties between European Union member states (Božič 2008). But the level of separation that has always marked cultural contact in Europe throughout history still remains: the 'Other' is our immediate neighbor. This is perhaps most eloquently problematized by the case of the bilingual Slovenian-Austrian region in Carinthia: in Radsberg/Radiše they sing carols already recorded in the Tinjska rokopisna pesmarica (Tajne/Tainach Manuscript Songbook) at the end of the $18^{\text {th }}$ century or beginning of the $19^{\text {th }}$ (Orožen (ed.) 2005: 7, 37). These carols were adopted by German settlers earlier than by the German-speaking neighbors with whom Slovenians have lived for many generations. In view of the surface closeness expressed by Christmas, perhaps these differences are even more visible. 
There is no doubt that a strong common heritage exists in Christian songs: many motifs confirm it. There are also many common songs spread throughout Europe, although holiday songs are not the best examples for revealing contact. The influence of religion was strong enough to enable both. But the question of whether a common European heritage is song heritage itself or the heritage of songs seems to provoke a further question: is it possible to study both without context? The story of Christmas songs proves that common tradition is not just the result of connections, but also the result of resistance.

The question of heritage in or using songs is therefore also a conceptual question for folklore studies itself, whether in Europe or elsewhere. The Ballad Commission strove for decades to reveal the connections and distinctions between European nations by studying the similarities of song motifs (Kumer 1998). Without understanding the common song tradition, this produces a rather one-sided image. Only the attitude towards accepting songs from others and understanding the context that accompanied that process reveal a perspective not just on understanding interculturality, but also on understanding our own culture. Despite the view that culture cannot be a sufficient source for social scientists (Dundes 1996: 35), social responsibility thus remains: the common song tradition is revealed not just by the songs, but also by the people that created them.

\section{REFERENCES AND SOURCES}

Blaumeiser, Heinz and Eva Blimlinger

1993 Weihnachten als soziale Zeit. Ein Nachwort. In: Blaumeiser, Heinz and Eva Blimlinger (eds.), Alle Jahre wieder ... Weihnachten zwischen Kaiserzeit und Wirtschaftswunder. Wien: Böhlau Verlag, 275-314.

Bowden, Henry Warren

1997 Puritanism, Puritans (http://mb-soft.com/believe/txc/puritani.htm).

Božič ...

2008 Božič v EU (http://www.evropa.gov.si/si/vsebina/novice/aktualne-teme/2008/bozic-v-eu/).

Brumen, Borut

1997 "Europe is to blame for everything" (Slovene stereotypes about Europe 1985-1992). In: Jezernik, Božidar and Rajko Muršič (eds). Prejudices and Stereotypes in the Social Sciences and Humanities. Ljubljana: Znanstveni inštitut Filozofske fakultete (Etnološka stičišča 5 \& 7), 136-142.

Ciciban ...

1949/1950 Ciciban. Revija za najmlajše. 4/4.

Cin ...

2007 Cin, cin, cin, zvončki pojejo (http://www.youtube.com/watch?v=9yBxqR3cOGQ).

Dundes, Alan

1996 (1989) Folklore Matters. Knoxville: University of Tennessee Press. 
Elwert, Georg,

2002 Switching Identity Discourses. In: Schlee, Günther (ed.), Imagined Differences. Hatred and the Construction of Identity. Munster: Lit Verlag, 33-54.

Glonar, Joža

1908-1923 Predgovor ... Slovenske narodne pesmi 4, 3-66

Haneke, Georg

2002 The Multidimensionality of Oromo Identity. In: Schlee, Günther (ed.), Imagined Differences. Hatred and the Construction of Identity. Munster: Lit Verlag, 133-153.

Hobsbawm, Eric

2002 (1983) Introduction. Inventing Traditions. In: Hobsbawm, Eric and Terence Ranger (eds.): The Invention of Tradition. Cambridge: Cambridge University Press, 1-14.

Jagodic, Jože

1918-1919 Postanek božične pesmi »Sveta noč, blažena noč«. Slovenska družina 1 (8): 187-188.

Jarc, Mojca

2009 Zadnji šolski dan (http://www.sfpkr.si/slike/0304/Prvi_razred/index7.htm).

Jingle ...

2004 Jingle Bells (http://www.carols.org.uk/jingle_bells.htm).

Kaiser, Birgit Mara

2002 Exclusivist Rhetorics. The Constitution of Political Identities in Present-Day Algeria. In: Schlee, Günther (ed.), Imagined Differences. Hatred and the Constuction of Identity. Münster: Lit Verlag, $183-214$.

Kamniškiob̌ran

1988 Kamniški občan 28 (20).

1989 Kamniškiobčan 29 (19).

Kolar, Bogdan

2002 Njih spomin ostaja. In memoriam III. Rajni salezijanci v prvih sto letih salezijanskega reda med Slovenci. Ljubljana: Salve.

Kramar, Frančišek

1933 Dobrepolje in okolica. Vol. 1. Narodne pesmi. Ljubljana: Dobrodelno društvo Varstvo v Ljubljani.

Kumer, Zmaga

1958 Slovenskeprireditve srednjeveške božičnepesmi Puernatus in Betlehem. Ljubljana: Slovenska akademija znanosti in umetnosti (Razprave; 3).

1995 »Mi smo priśli nócoj k vam «... Slovenske koledniške pesmi. Ljubljana, Kres.

1998 Pogled na dosedanje delo Baladne komisije / A View on the Work of the Ballad Commission Out so Far. In: Golež, Marjetka (ed.), Ljudske balade med izročilom in sodobnostjo / Ballads between Tradition and Modern Times. Ljubljana: ZRC SAZU, Založba ZRC, 31-35.

Kuret, Niko

1970 Praznično leto Slovencev 4. Starosvetne šege in navade od pomladi do zime. Celje: Mohorjeva družba.

1986 Slovenska koledniška dramatika. Ljubljana: Slovenska matica.

Lloyd, A. L.

1969 (1967) Folk Song in England. London: Panther Arts. 
Milčetić, Ivan

1917 Koleda u Južnih Slavena. Zbornik za narodni život i običaje Južnih Slavena 22: 1-124.

Milisavljevič, Lajko (ed.)

1999 Eno pesem hočmo peti. Koledovanje na Koroškem (CD). Klagenfurt: Krščanska kulturna zveza in Slovenski narodopisni inštitut Urbana Jarnika v Celovcu.

Muršič, Rajko

1999 On Globalisation, Westernisation, Popular Music and Similar Issues in the Times of the Transition of Post-socialist Countries. In: Muršič, Rajko and Borut Brumen (eds.), Cultural Processes and Transformations in Transition of the Central and Eastern European Post-Communist Countries. Ljubljana, Oddelek za etnologijo in kulturno antropologijo, Filozofska fakulteta, Univerza v Ljubljani (Etnološka stičišča; 9), 139-156.

Oblak, Vatroslav

1891 Doneski k historični slovenski dialektologiji. Letopis Matice slovenske za leto 1891, 66-153.

Orožen, Martina (ed.)

2005 Tinjska rokopisna pesmarica. Maribor: Slavistično društvo Maribor (Zora 40).

Rettet ...

2005 Rettet den heiligen Sankt Nikolaus und das Christkind!

(http://www.bayerische-prache.de/Index/Texte/2005/Rettet\%20den\%20Nikolaus.htm).

Rihtman-Auguštin, Dunja

1999 Santa Claus Executed, the Croatian Way. In: Muršič, Rajko and Borut Brumen (eds.), Cultural Processes and Transformations in Transition of the Central and Eastern European Post-Communist Countries. Ljubljana: Oddelek za etnologijo in kulturno antropologijo, Filozofska fakulteta, Univerza v Ljubljani (Etnološka stičǐšča; 9), 47-56.

Rupel, Mirko

1969 Valvasorjevo berilo [Valvasor’s Reader]. Ljubljana: Mladinska knjiga.

Russell, Ian

2006 Village Carols (http://www.villagecarols.org.uk/working.htm).

SNP 3

1904-07 Štrekelj, Karel (ed.), Slovenske narodne pesmi [Slovenian Folk Songs] 3. Ljubljana: Slovenska matica.

Smolik, Marijan

1993 Slovenski božič v novi zvočni podobi. Cerkveni glasbenik 86 (4-6): 35-36.

Stare ...

1940 Stare božične pesmi v Kropi (J. G.). Zadrugar. Glasilo »Plamena« kovinarske zadruge v Kropi, 3.

Trubar, Primož

1575 Katekizmus z dveima izlagama. Tübingen, Georg Gruppenbach.

Turnšek, Metod

1943 Pod vernim krovom 1. Ljubljana: Družba Sv. Mohorja v Ljubljani. 


\section{BOŽIČNE PESMI IN OBLIKOVANJE ISTOVETNOSTI}

Izhodišcno vprašanje, na katero se navezuje razprava, je bilo vprašanje obstoja in podob skupne evropske pesemske dedišcine. To dediščino, ki naj bi se izražala bodisi neposredno s skupnimi pesmimi bodisi v njih, skuša prispevek razkriti v slovenskih božičnih pesmih.

Neposredni izziv za opazovanje pestrosti pesemskega izročila in njihove sporočilnosti ponujajo družbene spremembe na Slovenskem v zadnjih dveh desetletjih. Vrnitev božičnih praznovanj $v$ slovensko javno življenje je namreč opozorila na raznovrstnost vplivov, ki so oblikovali in še oblikujejo podobo slovenskih božičnih praznovanj, in na raznovrstnost stikov Slovencev z drugimi narodi. Retrospektivni pogled tako zazna sledi skupne predkrščanske dediščine, ki se je v podobi Pehtre ohranila $v$ širšem alpskem prostoru, s slovensko pesmijo pa je povezana le še ob koledovanju na avstrijskem Koroškem. Sledi podobam zelo diferenciranega izročila, ki ga je oblikovala krščanska kultura: te sledi so na pesemski ravni odslikavale ne le vezi, temveč tudi razločke. Razhajanja, prepoznavna tudi v pesmi, je namrečv evropski prostor vnesel že protestantizem. Razločki so se ohranjali predvsem $v$ raznovrstnosti koledovanj, ki so imela versko in socialno ozadje. Ideološki istovetnosti in socialni raznolikosti, prepoznavni v pesmih, se je šele v 19. stoletju pridružilo iskanje nacionalne prepoznavnosti, ki je povzrocilo nova razhajanja. K podobi te diferenciranosti so prispevali družbeni pretresi 20. stoletja, ki so povzročili tako spreminjanje ideoloških orientacij kot istovetnosti.

Praznovanja imajo simbolno moč in božične pesmi tako nakazujejo večjo bližino, kakor jo kažejo družbeni procesi. To pa folkloristike nikakor ne odvezuje odgovornosti do preučevanja družbe oziroma nosilcev pesemske dedišcine. Vprašanje, ali imamo skupno dediščino pesmi ali v samih pesmih, tako nakazuje konceptualno vprašanje same vede: spoznavanje pesemskih motivov, ki je doslej združevalo člane Baladne komisije, je labko obšlo družbene okvire, preučevanje bližin v pesemski dedišcini evropskih narodov, torej dediščine samih pesmi, pa zahteva tudi razumevanje širšega družbenega konteksta. To namreč prav v Evropi pripoveduje tudi o razdaljah, ki so jih včasih premoščale tudi-ali pa samo - pesmi.

Dr. Marija Klobčar, Glasbenonarodopisni inštitut ZRC SAZU /Institute of Ethnomusicology SRC SASA, Novi trg 2, 1000 Ljubljana, Slovenia, marija.klobcar@zrc-sazu.si 